\title{
CORRECTION
}

\section{Correction to: Cannabis and public health—a need to reclaim the narrative}

\author{
Bobby P. Smyth ${ }^{1,2} \cdot$ Mary Cannon $^{3}$
}

Published online: 21 May 2021

(c) Royal Academy of Medicine in Ireland 2021

\section{Correction to: Irish Journal of Medical Science (2021) https://doi.org/10.1007/s11845-021-02570-x}

The article "Cannabis and public health-a need to reclaim the narrative", written by Bobby P. Smyth and Mary Cannon, was originally published online on the publisher's internet portal on 15 March 2021 with Open Access under a Creative Commons Attribution 4.0 International License.

With the author's/authors' decision to cancel Open Access the copyright of the article changed on 12 March 2021 to $\odot$ Royal Academy of Medicine in Ireland 2021 with all rights reserved.

The original article has been corrected.

The original article can be found online at https://doi.org/10.1007/ s11845-021-02570-x.

Bobby P. Smyth smythbo@tcd.ie

1 Department of Public Health and Primary Care, Trinity College Dublin, Dublin 2, Ireland

2 Adolescent Addiction Service, Bridge House, Cherry Orchard Hospital, Dublin 10, Ireland

3 Department of Psychiatry, RCSI University of Medicine and Health Sciences, Dublin 2, Ireland 